\title{
Diversity in education and the phenomenon of subtle marginalisation and infrahumanisation
}

\begin{abstract}
Beata Skotnicka, Diversity in education and the phenomenon of subtle marginalisation and infrahumanisation. Interdisciplinary Contexts of Special Pedagogy, no. 27, Poznań 2019. Pp. 53-82. Adam Mickiewicz University Press. ISSN 2300-391X. e-ISSN 2658-283X. DOI: https:/ / doi.org/10.14746/ikps.2019.27.03
\end{abstract}

The article focuses on the issue of diversity in education. The aim of the study is to present the results of research on the perception of shared education of students with and without disabilities and to choose the most favourable form of education for students with disabilities. Awareness and legitimacy of these actions is widespread, but sometimes it is limited to declarations. The article posits the thesis that the condition for the effective pursuit of inclusive education is first of all a maturity for diversity and an internal consent to it, which manifests itself in attitudes that accept student with disabilities in a public school space. The article presents theoretical contexts regarding the issue of normalisation, subtle marginalisation and infrahumanisation.

KEY WORDS: student with disability, diversity, inclusive education, marginalisation, infrahumanisation

\section{Introduction}

Social, cultural and economic changes initiated in the 1990s have been reflected in changes in the perception of disability and people with disabilities. The principle of normalisation of life of people 
with disabilities and integration aspirations have given rise to changes in the education system of people with disabilities. The implementation of the Convention on the Rights of Persons with Disabilities and the Salamanca Declaration was a step towards inclusion. After more than thirty years, inclusion policy has become a universally accepted mainstream and has encompassed all areas of social life, including education. Along with the changes in the social perception of people with disabilities, there have been changes in thinking about people with disabilities and their place in society. People with disabilities have been included in the mainstream of social life on an equal footing with other participants. The policy of equal opportunities resulting from the assumptions of inclusive education created the possibility of taking advantage education adapted to their needs and abilities, in a school located closest to their place of residence. Despite the fact that inclusive education is part of the Polish educational system, the conviction about common education in a single educational space - a public school - raises many reservations, which are based on the welfare of students with disabilities as seen from the perspective of people without disabilities. The challenge for the modern world has become the ability to function in a diverse society and to accept this diversity. Inclusive education plays an important role in promoting diversity and the fundamental values of a democratic society - tolerance, openness to diversity, respect for the dignity of each person. It prevents discrimination and promotes respect for human rights. Inclusion is a broad concept, covering all areas of social life. In terms of education, it is a process of change, a way of thinking, a culture that entails increasing the accessibility of teaching through diversity, the creation of individual curricula, respect for diversity and culture of all participants in the educational process. Readiness for inclusion cannot be imposed - it must be grown into.

Therefore, the aim of this paper is to present the results of research on the perception of shared education of students with and without disabilities, as well as on the choice of the most beneficial form of education for students with disabilities by students of 
pedagogical faculties. Both the research goal and the position I adopt allow for the development of the thesis that the condition for effective inclusive education is, above all, maturity to diversity and internal consent to it, which is manifested in the attitudes accepting student with disabilities in the public school space. The perception of the place of students with disabilities in the common educational space is an expression of the normalisation activities carried out for several decades in special education. Awareness and legitimacy of these actions are common, but sometimes they are confined to declarations. Although we agree that every child, regardless of their limitations, has the right to education in a school located as close as possible to their place of residence, in practice we often look for reasons to deny them this right in the best interests of the child. In some cases, by declaring willingness to participate together in social life on an equal footing with people with disabilities, we subconsciously depreciate their ability and right to this participation. Therefore, in the further part of this article, I will present the issue of normalisation, which will provide a basis for further considerations on its implementation in educational practice.

\section{Normalisation in the sphere of creation}

The concept of normalisation was developed in the 1950s and 1960s in Scandinavian countries. The term "normalisation" was first used in 1959 in the preamble to the Danish Social Welfare Act on the initiative of Niels Erik Bank-Mikkelsen. ${ }^{1}$ In a text published ten years later in the United States, Bengt Nirje detailed the principle of normalisation by distinguishing its eight components: normal rhythm of a day, normal rhythm of the week, normal rhythm of the year, normal life-cycle, recognition of the expectations and preferences of the individual (subjectivity), normal heterosexual contacts,

${ }^{1}$ N.E. Bank-Mikkelsen, A metropolitan area in Denmark: Copenhagen, [in:] Changing patterns in residential Services. For the mentally retarded, R. Kugel, W. Wolfensberger (eds.), President's Committee on Mental Retardation, Washington 1969. 
normal economic standard, normal living conditions. ${ }^{2}$ Normalisation is both the target state and the process of achieve it. These are activities aimed at enabling people with disabilities to achieve education, life experiences, social status and living conditions considered typical (normal), standard for a given social group. Normalisation is therefore the improving the lives of people with disabilities in various areas of their lives. In Poland, the concept of normalisation was introduced and disseminated by Amadeusz Krause, according to whom normalisation is all institutional and non-institutional actions aimed at creating normal living conditions for people with disabilities and providing them with such assistance that they can function normally throughout their lives, to the extent it is possible". ${ }^{3}$ Aleksandra Maciarz believes that the spectrum of normalisation activities should be included in such aspects as

- humanisation of social life strengthening the acceptance of people with disabilities by members of society, their subjective functioning in society and pro-social attitudes towards them;

- support of the society for persons with disabilities in meeting their psycho-biological needs, access to education, culture, work and all forms of human activity that are accessible to people without disabilities;

- adaptation in terms of organisation, technology and culture of the various institutions, facilities and services used by members of a given community to the individual needs of persons with disabilities;

- inclusion of persons with disabilities in various areas of life and situations of the community, while maintaining their autonomy, subjectivity and partnership with people without disabilities;

- enabling people with disabilities to lead their daily lives in a natural environment, at a normal rhythm (day, week, year)

2 N.E. Bank-Mikkelsen, Warunki życia dla ludzi z upośledzeniem umysłowym, Bruksela 1991.

${ }^{3}$ A. Krause, Integracyjne złudzenia ponowoczesności, Oficyna Wydawnicza „Impuls", Kraków 2000, p. 24. 
and in accordance with environmental cultural patterns (eating at specified times, working, resting, celebrating, etc.), taking into account their individual needs and abilities. ${ }^{4}$

It should be noted, however, that today's normalisation is not a rigidly defined idea, as it was decades ago. It is constantly being enriched by new theoretical constructs, modified and strengthened by research analyses. The results of empirical studies allow for people with disabilities to be more fully seen in different areas of their functioning. 5

One of the manifestations of the normalisation of living conditions is ensuring equal access to education for all students, regardless of their state of health, disability or other conditions. Normalisation is not only an adaptation of the living environment, but also, and perhaps above all, a change in the way of thinking and perceiving people with disabilities, from inferior or not having right to equal and full rights.

According to Teresa Żółkowska, normalisation is an "unfinished theory of practice", which not only imposes, organises, and is a power, but which is open to changeability, perceiving the multiplicity of experiences. "It is not about staying outside of reality, creating an unreal world. People with disabilities, like everyone else, should have a chance to reflect on themselves, but they must do so in the real (normal) world". 6 As Żółkowska further notes, "when creating a theory of the participation practices of people with disabilities, it is not necessary to look for and describe what is normal and what is not, only to recognise the multiplicity and diversity of

${ }^{4}$ A. Maciarz, Normalizacja szansa likwidacji społecznego upośledzenia osób niepetnosprawnych, [in:] Z. Janiszewska-Nieścioruk (ed.), Sfery życia osób z niepetnosprawnościa intelektualna, Oficyna Wydawnicza „Impuls”, Kraków 2005.

${ }^{5} \mathrm{~J}$. Głodkowska, „Autorstwo życia a niepełnosprawność - ponawiane odczytywanie idei normalizacji", [in:] Człowiek - Niepetnosprawność - Społeczeństwo 2014, no 1.

${ }^{6}$ T. Żółkowska, "Normalizacja niedokończona teoria praktyki”, Niepetnosprawność, 2011, no. 5, p. 89. <http://bazhum.muzhp.pl/media//files/Niepelnospraw nosc/Niepelnosprawnosc-r2011-t-n5/Niepelnosprawnosc-r2011-t-n5-s85-93/Niepel nosprawnosc-r2011-t-n5-s85-93.pdf> [accessed on 15.02.2019]. 
these worlds". ${ }^{7}$ The recognition of diversity as a determinant of our times is a prerequisite for normalisation activities. The social world is a diverse world, presenting a spectrum of different cultures, material statuses, levels of education, places of residence and levels of ability. It is this diversity that makes our lives colourful and varied. This diversity includes people with disabilities as part of society. Normalisation is inseparable from the category of the time and space in which it takes place. Changing governments, amendments to the educational laws and changes in the social awareness of people with disabilities mean that it is still in the sphere of creation. One of the normalisation activities is the inclusion of students with disabilities in mainstream schools and the creation of a friendly educational space adapted to the needs of all participants of the educational process. A change in thinking about adapting the space to the needs of all participants of social life is a universal design understood as an approach to planning and creating products, equipment and public spaces, which ensures their accessibility for all users. One of the most important objectives of universal design is to promote equality and ensure the full participation of people with disabilities in society by removing existing barriers and preventing the emergence of new ones. ${ }^{8}$ Universal design puts the user first, increasing the accessibility of services, objects and facilities, which is a prerequisite for ensuring equal opportunities for people with disabilities. Although universal design is associated primarily with infrastructure projects, it is also used in so-called soft projects. ${ }^{9}$ The aim of this type of design is to prevent marginalisation and exclusion of people with disabilities in particular. I will discuss this issue in the next section, presenting its various forms.

7 Ibid., p. 90.

8 Realizacja zasady równości szans $i$ niedyskryminacji, w tym dostępności dla osób $z$ niepetnosprawnościami. Poradnik dla realizatorów projektów i instytucji systemu wdrażania funduszy europejskich 2014-2020, Ministerstwo Rozwoju, Warsaw 2015, <https:// www.pois.gov.pl/media/23675/publikacja_wersja_kontrastowa_3.pdf> [accessed on 10.03.2019].

${ }^{9}$ Ibid., p. 24. 


\section{"Other - Alien" and subtle marginalisation and infrahumanisation}

The issue of marginalisation is present in the literature on sociology, psychology and pedagogy and is related to the problems of different groups with their participation in social life. K.W. Frieske states that "in societies we know from historical sources, as well as in modern societies, we see the presence of people who, for various reasons, participate in the collective life to a lesser degree than others" ${ }^{10}$ For years, one such group has been people with disabilities. Disability was a stigma, a pejorative mark on a person, resulting in marginalisation and exclusion. Social transformations have changed the perception of people with disabilities. As Amadeusz Krause notes, "it can be said that traditional stigmatisation and social exclusion of people due to disability are disappearing, and their manifestations are not socially acceptable". ${ }^{11}$ According to Krause, this situation does not mean, however, that people with disabilities have equal status and therefore equal opportunities. He states, "we are dealing with a new phenomenon of subtle marginalisation, in which declarations of acceptance are accompanied by a social distance towards people with disabilities, consisting in the representation of opposing attitudes by one person, namely an open positive and hidden negative attitude. This may be a conscious phenomenon when we are aware of but conceal our opinions or unconscious biases". 12

Another concept related to marginalisation is the concept of infrahumanisation. Introduced into the field of psychology by JaquesPhilippe Leyens, ${ }^{13}$ it means a tendency to perceive innate human

${ }^{10}$ K.W. Frieske, Encyklopedia Socjologii, Wydawnictwo Naukowe, Warsaw 1998.

11 A. Krause, A. Żyta, A. Nosarzewska, Normalizacja środowiska społecznego osób $z$ niepetnosprawnością intelektualną, Wydawnictwo Edukacyjne „Akapit”, Torun 2010, p. 28.

12 Ibid., p. 56.

13 J.P. Lyens, S. Demoulin, J. Vaes, R. Gaunt, M.P. Paladino, “Infra-humanization: The Wall of Group Differences", Social Issues and Policy Review 2000, No. 1. 
traits as much weaker in members of alien groups in comparison to one's own group (people without disabilities - people without disabilities; people with disabilities - people with disabilities) than in the group of "Others" (people without disabilities - people with disabilities), and their survival results from cultural frameworks and individual experiences. We attribute to a stronger experience of secondary emotions to "us" than to "them". Therefore, the effect of infrahumanisation will occur in every context of group comparisons, regardless of the content of stereotypes. According to the assumptions of the Stereotype Content Model, ${ }^{14}$ how we perceive others can lead to different emotions that we will feel about them and, as a result, to different behaviours. Foreign groups may be objects of aversion or envy, and as a result of open hostility or pity, which may lead to a desire to help, but also to exclusion. ${ }^{15}$ According to Stephanie Demoulin, infrahumanisation is a phenomenon that occurs automatically and unconsciously in everyday intergroup relations. The perception of "others" as less human is a kind of continuum of marginalisation and exclusion - from the most subtle forms present at the unconscious level to the overt, conscious dehumanisation called "delegitimisation" or "moral exclusion". ${ }^{16}$ In her considerations of the phenomenon of infrahumanisation in the

14 The Stereotype Content Model is a concept proposed by Susan Fiske and colleagues (2002), explaining the relationship between social perception, intergroup emotions and tendencies to specific behaviour towards "other" groups. It describes the content in a two-dimensional space of warmth and competence, which plays a key role in the process of formulating social judgements. This theory presupposes the existence of ambivalent forms of prejudice and the resulting different forms of discrimination. The authors of the theory emphasise that homogeneous positive or negative stereotypes are less frequent than ambivalent ones.

15 M. Wiśniewski, A. Haska, Społeczna mapa stereotypów, Centrum Badań nad Uprzedzeniami, Warsaw 2012, <http://cbu.psychologia.pl/uploads/Raporty\%20\%20Deconspirator/Winiewski\&Haska_Deconspirator_mapa\%20stereotypow.pdf> [accessed: 4.08. 2019].

16 S. Demoulin, R.T. Rodriguez, A.P. Rodriguez, J. Vaez, M.P. Paladino, R. Gaunt, B.P. Cortes, J.P. Leyens, "Emotional prejudice can lead to infrahumanization”, European Reviev of Social Psychology, 2004, no. 15, pp. 269, 259-296. 
context of people with disabilities, Magdalena Bełza states that "political correctness requires a good attitude towards people with disabilities, so it is easy to hear positive assessments of this group of people, but actions reveal the true nature of this attitude, revealing feigned anti-discrimination attitudes. ${ }^{17}$ As the author further notes, the infrahumanisation of people with disabilities results in reactions of instinctive attribution of a certain stereotype, induced by the appearance of a prime, i.e. a signal specific to a given category. The sight of a wheelchair or a white cane triggers the reaction of automatically classifying these people as "them" or "us" depending on the identity of the person interacting with the other person or group. An abled-bodied person classifies a person with a disability as an "other". ${ }^{18}$ Magdalena Bełza concludes that "unlike the phenomenon of dehumanisation, which frequently appeared in special pedagogy in relation to people with disabilities, infrahumanisation does not require a conflict situation and often does not take on extreme forms. Neither does it have to mean delegitimisation, i.e. the taking away of fundamental rights from 'others'". 19 Therefore, as J.P. Leyens says, this phenomenon occurs wherever there is a division into "us" and "them", even if these groups lead a neutral coexistence. ${ }^{20}$ In the case of disability, there is a specific type of imposition of two kinds of otherness: other, because they are another person, and other, because they have a disability. Such an increase in otherness becomes the source of perceiving a person with a disability as not only different, but also alien. ${ }^{21}$ This situation means that even as we declare our openness to "others", we are not mentally

${ }^{17}$ M. Bełza, „Ableizm a zjawisko infrahumanizacji 'obcych'”, Teraźniejszość-Człowiek-Edukacja, 2016, no. 2, p. 80.

18 Ibid., p. 81.

19 Ibid., p. 84.

20 After: T. Baran, „Pomiar zjawiska infrahumanizacji 'obcych' poprzez atrybucję słów typowo ludzkich i typowo zwierzęcych", Psychologia Społeczna, 2011, vol. 6, 3(18), p. 203.

${ }^{21}$ J. Głodkowska, "Autorstwo życia a niepełnosprawność - ponawiane odczytywanie idei normalizacji", [in:] Człowiek - Niepetnosprawność - Społeczeństwo 2014, no. 1, p. 76. 
ready for it. How then do we limit the tendency to infrahumanisation? Monika Tarnowska, analysing the conditions of infrahumanisation, states that a similarity in terms of key beliefs makes the "others" seem less antagonistic, which leads to a limited conflict between the "us" and "them" groups. ${ }^{22}$ Intergroup cooperation increases positive attitude towards the "others". The representation of two different groups is replaced by the representation of a common group pursuing a common objective. ${ }^{23} \mathrm{~A}$ similar position regarding cooperation is presented by D.W. Johnson and R.T. Johnson. The authors believe that cooperative learning is a particularly important educational strategy from the perspective of inclusion and diversity. ${ }^{24}$ These interactions are about creating the feeling that "we" and "they" belong to a larger social whole, that we have common values and that we are fundamentally similar to each other. Such a goal is inclusive education, which allows all its members (students), regardless of differences and possibilities, to function together and achieve goals. Such actions may contribute to the creation of a superior, inclusive category, which includes representatives of both one's own group and the "other" group, which in turn should contribute to the social inclusion and weakening of infrahumanisation processes for the benefit of common functioning in a shared school space.

\section{Readiness for diversity}

In the era of globalisation, diversity is inscribed on the map of our times as a phenomenon that is becoming more and more common. It is considered to be a value of contemporary, (post)modern

${ }_{22}$ M. Tarnowska, „Kiedy odmawiamy 'obcym' człowieczeństwa? Uwarunkowani zjawiska infrahumanizacji”, [in:] M. Kofta, M. Bilewicz (eds.), Wobec obcych. Zagrożenia psychologiczne a stosunki międzygrupowe, Wyd. Naukowe PWN, Warsaw 2011, p. 169.

23 Ibid.

${ }^{24}$ See. D.W. Johnson, R.T. Johnson, “Cultural Diversity and Cooperative Learning", [in:] Cooperative Learning and Strategies for Inclusion, J.W. Putman (ed.), Maple Press, New York 2010, pp. 76-83. 
societies. The concept of diversity can be interpreted in many ways, depending on the context in which it is considered. With regard to society, we can say that diversity is all aspects in which people differ, both apparently - in terms of age, gender, race, fitness - and invisibly - in terms of education, knowledge, experience, skills and competences, personality, beliefs, value system, identity, culture. ${ }^{25}$

In this paper, I describe diversity as the joint functioning of students with and without disabilities in a public school environment. This approach is consistent with the recognition and appreciation of the differences between students in favour of taking action and treating diversity as a value consistent with the demands of the "Learning - the treasure within" Delors report concerning the pillars of education, and in particular one of them - "learning to live together". Diversity can give rise to fears of the unknown, fear of the "others" or anxiety about the threat to the achievement of one's own goals and needs. Categories of Other/Alien are popular in sociology, multi-cultural and intercultural education. ${ }^{26}$ Otherness may arouse different emotions, both positive and negative, constitute a criterion of divisions, alienation, generate difficulties related to participation in education, and even constitute a factor of exclusion from it and social life. ${ }^{27}$ In special education, this category is used to describe the situation of people with disabilities. ${ }^{28}$ Magdalena Bełza, describing the situation of students with disabilities in the folklore of the school, writes: "The place of a student with a dis-

25 These categories correspond to the highlighted diversity features described by Mary Loden in the Diversity Wheel, see M. Loden, Implementing Diversity, Irwin Publishing, Chicago 1996.

26 See M. Kofta, M. Bilewicz (eds.), Wobec obcych, Wydawnictwo Naukowe PWN, Warsaw 2011; P.P. Grzybowski, Edukacja międzykulturowa - konteksty. Od tożsamości po język międzynarodowy, Oficyna Wydawnicza „Impuls”, Kraków 2011.

27 Z. Bauman, Socjologia, Wydawnictwo Zysk i S-ka, Poznań 1996, p. 49.

28 See Z. Gajdzica, Z, Uczniowie i studenci z obszaru pogranicza wobec sytuacji osób niepetnosprawnych w środowisku lokalnym - nastawienia i opinie. Raport z badań, Wydawnictwo Arka, Cieszyn-Skoczów 2013; I. Chrzanowska, Pedagogika specjalna. Od tradycji do wspótczesności, Oficyna Wydawnicza „Impuls”, Kraków 2015, et al. 
ability in the folklore of the school and the degree of intensity of their otherness, or the Other/Alien stigma, is determined by the placement of the student in a specific form of education. Depending on the type of school, the student is one of many, who does not stand out in any particular way (because most pupils may have similar problems), or will stand out from other pupils in terms of their diversity, something particular" ${ }^{29}$ In analysing the situation of a student with a disability in various forms of education, Bełza states that in a mainstream school the fact of having a disability comes becomes the most important factor, determining not only the education itself, but above all what surrounds it, i.e. being a student and a classmate. Disability becomes the cause of being an Other/Alien in a group. It is more visible because it is the reason why a student is different. ${ }^{30}$ Are we then ready for diversity?

The concept of readiness can be considered in different ways. It is most often considered in pedagogy in the context of school readiness. ${ }^{31}$ Krystyna Duraj-Nowakowa distinguishes "professional readiness" by stating that the analysis of the notion of "professional readiness" - by analogy to the meanings of the term "mental readiness" - allowed for distinguishing two basic ways of defining it. The first is to capture readiness in the personality aspect, the second is to capture readiness in the functional aspect. ${ }^{32}$ Beata Skotnicka believes that the concept of professional readiness may relate to maturity - teachers' readiness to work with a child with disabilities. In the author's opinion, it is worth looking at the problem in a wider perspective and considering it not only as a child's maturity for

${ }^{29}$ M. Bełza, „Inny/Obcy (uczeń niepełnosprawny) jako podmiot 'folkloru' szkolnego", [in:] Inkluzja edukacyjna. Idee, teorie, koncepcje, modele edukacji włączajacej a wybrane aspekty praktyki edukacyjnej, Wydawnictwo Uniwersytetu Śląskiego, Katowice 2016, p. 105.

30 Ibid., p. 108.

31 B. Wilgocka-Okoń, Gotowość szkolna dzieci sześcioletnich, Wydawnictwo Akademickie Żak, Warsaw 2003.

32 K. Duraj-Nowakowa, Kształtowanie profesjonalnej gotowości pedagogów, Wydawnictwo WAM, Kraków 2011. 
learning, but also as teachers' maturity in mainstream institutions for working with a child with disabilities. ${ }^{33}$

When analysing the concept of maturity (readiness), which is usually considered in relation to the student, in this paper I consider it to be the social readiness for diversity, understood as a common education of students - with and without disabilities - in inclusive education. The diversity resulting from the common functioning of all students should not be a problem, but a pedagogical challenge. The readiness for diversity is therefore expressed in the full acceptance of all participants in social processes, regardless of the categories of diversity mentioned above. The research carried out by the author, which is presented later in this article, is an example of the readiness for diversity perceived in this way.

\section{Author's own research project}

The main aim of the research was to find out and consider the opinions of students of pedagogical faculties concerning the selection of the most beneficial form of education for students with disabilities. The indirect objective was to check the openness (readiness) to inclusion activities that express the acceptance of common education of students with and without disabilities, preventing marginalisation and exclusion of this group of students. The research was diagnostic in nature. The subject of the research were the declarations of students concerning joint education of students with and without disabilities, as well as the selection of the most beneficial form of education for students with disabilities in the Polish educational system. These declarations comprise a collection of information constituted on the basis of respondents' own convictions and observations concerning inclusive reality, and in my opinion, they reflect attitudes towards inclusive activities. Therefore, it can

33 B. Skotnicka, „Gotowość do realizowania edukacji włączającej przez nauczycieli w szkołach ogólnodostępnych", Nauczyciel i szkoła 2015, no. 1, p. 74. 
be assumed that the opinions of students of pedagogical faculties, as future educators, may be an indicator of the actual circumstances of inclusive education and what is inseparably connected with it openness to diversity. This article, due to its limited framework, presents selected results concerning the perception of joint education of students with and without disabilities in the public school space.

The surveyed students were asked the question: In your opinion, is the joint education of students with and without disabilities beneficial for both groups? Next, the respondents were asked: What form of education do you think is best for a student with a disability? They were then asked to justify their choice.

In order to obtain answers to the research questions, the diagnostic survey method using the questionnaire technique was used. Closed and open questions were used in the questionnaire. The leading method was quantitative research supplemented by qualitative analysis of the justification of the choice of the most beneficial form of education for students with disabilities by participants, which constituted an exemplification of quantitative research.

213 students of pedagogical faculties took part in the research: 86 students of Early Childhood Education, 74 students of Education, 53 students of Speech and Language Pathology. All respondents were women aged 21-23. In the course of their studies, they studied Special Education, within which they became acquainted with the issues of disabilities, working with students with disabilities and forms of education of these students in the Polish educational system.

\section{The best form of education for students with disabilities - analysis of research results}

In the Polish educational system, a student with a disability is one who has a certificate stating their need for special education issued by a public psychological and educational counselling centre. 
Despite the recommendations contained in the certificate on the need for special education concerning the choice of the form of education, the final decision is left to the parents or legal guardians of the child. Therefore, students with disabilities can benefit from any of the three forms of special education: special, integrated or mainstream school. Each of these facilities should be prepared for the reception and education of such a student. This preparation concerns not only infrastructure, teaching aids, curricula and specialised staff, but also our mentality and internal conviction that it is right to educate both groups of students in a shared classroom and school space.

Analysis of the answers concerning the benefits of joint education of students with and without disabilities showed that the vast majority $-82 \%$ of respondents - chose the answer definitely yes, stating that joint education of students with and without disabilities is beneficial for both groups, while $15 \%$ of respondents answered probably yes. Only 3\% chose the answer probably not. None of the students surveyed gave a definitely not answer.

The data collected by Karolina Mudło-Głagolska and Marta Lewandowska, who analysed the opinions of teachers of mainstream schools on inclusive teaching of students with disabilities, showed similar results. The results obtained by the authors indicate that more than $80 \%$ of respondents believe that students with disabilities have the right to education in a mainstream school. Less than $9 \%$ of the total sample denied this right, identifying a special school as an appropriate place for the education of students with disabilities. ${ }^{34}$

In a further section of the survey, students were asked to choose what they thought was the best form of education for a student with disabilities. The analysis of the research results is presented in the table below with the distinction of the fields of study of the respondents.

${ }^{34}$ K. Mudło-Głagolska, M. Lewandowska, „Edukacja inkluzyjna w Polsce”, Przegląd Pedagogiczny 2018 no. 2, p. 208. 
Table 1. Student opinions on the best form of education for students with disabilities

\begin{tabular}{|c|c|c|c|c|c|c|c|c|}
\hline \multirow{3}{*}{ Field of study } & \multicolumn{8}{|c|}{ Form of education organisation } \\
\hline & \multicolumn{2}{|c|}{$\begin{array}{l}\text { Special } \\
\text { school }\end{array}$} & \multicolumn{2}{|c|}{$\begin{array}{l}\text { Integrated } \\
\text { school }\end{array}$} & \multicolumn{2}{|c|}{$\begin{array}{l}\text { Mainstream } \\
\text { school }\end{array}$} & \multicolumn{2}{|c|}{ Total: } \\
\hline & $\mathrm{N}$ & $\%$ & $\mathrm{~N}$ & $\%$ & $\mathrm{~N}$ & $\%$ & $\mathrm{~N}$ & $\%$ \\
\hline $\begin{array}{l}\text { Early Childhood } \\
\text { Education }\end{array}$ & 21 & 24.5 & 52 & 60.5 & 13 & 15 & 86 & 100 \\
\hline Education & 14 & 19 & 54 & 73 & 6 & 8 & 74 & 100 \\
\hline $\begin{array}{l}\text { Speech and Language } \\
\text { Pathology }\end{array}$ & 11 & 21 & 32 & 60 & 10 & 19 & 53 & 100 \\
\hline Total: & 46 & 22 & 138 & 65 & 29 & 13 & 213 & 100 \\
\hline
\end{tabular}

$\chi^{2}=4,617(\mathrm{df}=4) \mathrm{p}=0,329$ ni.

Source: Own compilation.

The analysis of the answers given shows that in the opinion of Early Education students, the best form of education for a student with disabilities is an integrated school. This form was indicated by over $60 \%$ of respondents. Every fourth respondent indicated a special school and only 15\% chose a mainstream school as the best form of education for this student. Students of Education also indicated an integrated school as the best form of education for students with disabilities. This was the response of the majority of respondents $73 \%$. One fifth of the respondents indicated a special school, and not many - $8 \%$ - chose a mainstream school.

Among the Speech and Language Pathology students, $60 \%$ of those surveyed indicated an integrated school as the best form of education for students with disabilities. Answers concerning the choice of a special school (21\%) and a mainstream school (19\%) were at a similar level. In comparison with the indications of students of Education and Early School Education, the students of Speech and Language Pathology indicated a mainstream school more frequently than their predecessors. The reason for this may be that, as future speech therapists, they are more prepared to work with children with various types of developmental deficits. On the 
basis of the $x^{2}$ test, there were no statistical relationships between the choice of the best form of education for students with disabilities and the field of study of the respondents.

The presented data corresponds with the results collected and analysed elsewhere by Beata Skotnicka. ${ }^{35}$ In investigating the attitudes of rural school teachers to inclusive education, the author states that over half of rural school teachers ${ }^{36}$ believe that the best system of education for children with a declared need for special education is an integrated class. The second form of education indicated by the teachers was an integrated school. One fifth of the respondents claimed that a special school is a good solution, while a mainstream school was indicated by the fewest respondents as the most advantageous form of education for a student with a certified need for special education. ${ }^{37}$

The analysis of the research results showed that over half of the people surveyed - 65\% - declared integrated schools as the best form of education for students with disabilities. Students most often justified their choice with the need for cooperation and functioning of students with and without disabilities in one class, to the benefit of both groups:

"In an integrated school, a child is not isolated from their peers, can work with them and learn from them", "An integrated school does not have such specific conditions and such a wide range of specialists as a special education school, but it is more accessible for people with disabilities than a mainstream school, and at the same time ensures integration with people without disabilities and adaptation to the social environment, which a special education school does not", "Healthy children learn tolerance towards 'otherness' and sick children do not feel rejected by society," "A child in an integrated school has special

${ }^{35}$ B. Skotnicka, „Przygotowanie ogólnodostępnej szkoły wiejkkiej do pracy z dzieckiem z orzeczoną potrzebą kształcenia specjalnego (na przykładzie szkół powiatu bydgoskiego)", unpublished part of doctoral dissertation

${ }^{36}$ The study group consisted of 145 teachers of rural schools in the Bydgoszcz district.

${ }^{37}$ B. Skotnicka, Przygotowanie..., op. cit. 
care, but is not excluded from life alongside their peers without disabilities, as they would be in a special school".

Katarzyna Ćwirynkało and Agnieszka Żyta take a different stance in researching teachers' beliefs about inclusive education for students with special educational needs. The analysis of the results of their research shows that teachers indicate that integrated education may have a negative impact on students with disabilities (their self-esteem, educational results). ${ }^{38}$ Jarosław Bąbka, ${ }^{39}$ Zenon Gajdzica, ${ }^{40}$ Katarzyna Parys, 41 and others also point to the unfavourable position of a child with a disability in the class.

Another argument was the presence of a supporting teacher and specialists prepared to work with a child with disabilities:

"[...] a child with disabilities can live and learn with children without disabilities and has constant aid from a supporting teacher", "In an integrated school, students have the opportunity to work together and at the same time have access to professional help, which is not available in mainstream schools".

Another argument is their own experience of integrated school education:

"I myself attended an integrated school and saw how well children work together and I know that for those of us without disabilities

${ }^{38}$ K. Ćwirynkało, A. Żyta, „Przekonania nauczycieli na temat edukacji włączającej uczniów ze specjalnymi potrzebami edukacyjnymi. Raport z badań", Szkoła Specjalna, 2015, no. 4.

39 J. Bąbka, „Psychologiczne aspekty efektywności edukacji dzieci w systemie integracyjnym”, [in:] Z. Kazanowski, D. Osik-Chudowolska (eds.), Integracja osób niepetnosprawnych w edukacji i integracjach społecznych, Wyd. UMCS Lublin 2003.

40 Z. Gajdzica, „Opinie nauczycieli szkół ogólnodostępnych na temat edukacji włączającej uczniów z lekkim upośledzeniem umysłowym w kontekście toczące się reformy kształcenia specjalnego", [in:] Z. Gajdzica (ed.), Uczeń z niepetnosprawnościa w szkole ogólnodostępnej, Oficyna Wydawnicza Humanitas, Sosnowiec 2011.

${ }^{41}$ K. Parys, "Gotowość młodzieży gimnazjalnej do integracji pozaszkolnej z niepełnosprawnymi rówieśnikami", [in:] J. Szempruch (ed.), Edukacja wobec wyzwań i zadań wspótczesności i przyszłości, Wyd. UR, Rzeszów 2006. 
working with those with disabilities is a good experience", "I learned how to accept people with disabilities and treat them as equals", "[...] it was there that I learned that there is no difference between me and a person with disabilities".

Some respondents believe that an integrated school is better for a student with disabilities than a mainstream school, justifying their choice:

"In an integrated school, students have better access to specialist teaching aids than in a mainstream school, and classes are smaller", "Students with disabilities often cannot cope with the conditions of a general school, which makes them feel worse and separate from the group", "[...] the student does not feel the stress of not keeping up with the material and has contact with children without disabilities, like in a mainstream school", "I think that an integrated school would be a better choice because a mainstream school does not fully meet the needs of a child with disabilities".

The surveyed students also drew attention to the stigma of the special education school:

“Often the very name 'special education school' has a negative impact on young people. Children from special education schools are often stigmatised and considered worse than others", "[...] in such a school, the students are not labelled and segregated. Everyone needs contact and no one wants to be excluded".

One in five respondents (22\%) indicated a special education school as their preference. Justifying their choice, they most often pointed to the high quality of special school education, good preparation of the school, infrastructure, curricula for the needs of students with disabilities and high-quality specialist staff fully prepared to work with students with various disabilities.

"Special education schools are best prepared for the needs of children with disabilities. Personnel are trained accordingly. A child can develop and learn in an individual way", "I believe that there is a specialised teaching staff in a special education school, students are under the best 
care because teachers are specially prepared to work with such children", "Teachers in a special school better understand students with disabilities and can satisfy their needs better than in a mainstream school", "I choose a special education school because such a school is prepared for the various problems of children with disabilities. The teaching staff, apart from the appropriate qualifications, is also more open, which facilitates contact with these students", "The special education school is the best in my opinion because it creates appropriate conditions for the development and self-development of the child, compensates for deficiencies and helps with comprehensive development", "In the special education school the student with a disability has full support from specialists".

Another factor deciding about the selection of a special school was the smaller number of students in classes. The respondents justified their choice in this way:

"Students learn in smaller classes than in mainstream schools, so the teacher can reach each student individually. Education at such a school is accessible to the student". "In my opinion, the best form is a special education school because the student has opportunities for better development. The schools use special teaching methods led by specialists, as well as adapted classrooms and smaller class sizes, which results in a better focus on each student".

A significant number of respondents, when selecting the special education school, pointed to the lack of acceptance of students with disabilities by their peers without disabilities in mainstream schools:

"[...] in a special education skill, the child with a disability is among other sick people, and so they do not feel rejected", "The child feels better among peers who have similar problems", "The student feels at ease, it does not matter that they are different", "In such a school, there is no aggression against people with disabilities by healthy peers", "The special education school meets all the needs of children with disabilities. There they are not ridiculed, pointed at", "[...] I am afraid that in integrated schools, and especially in mainstream schools, healthy 
children are not able to fully accept a peer with disabilities", "In a special education school, the child will not have to fear rejection or lack of acceptance by other peers", "In a mainstream school, students are suppressed by healthy people, which can cause a sense of inferiority", "[...] in a special education school, there is no risk of ridicule, rejection or abuse of students with disabilities by healthy children", "students with disabilities have more difficulties in learning, so they cannot keep up with others and in the mainstream school, they would feel worse, so I believe that the special education school is better for them because there, they can work at their own pace", "in a special education school, a student with a disability is among their own and does not feel alienated, especially when, for example, they are the only one in a class in a mainstream school".

The respondents' concerns about the lack of acceptance of students with disabilities in mainstream schools have been confirmed by research conducted both in the past decades and at present time. They reveal that these students are exposed to rejection and isolation. Maria Chodkowska's research shows that $69 \%$ of students with disabilities are rejected in mainstream classes by peers without disabilities. ${ }^{42}$ Anna Zamkowska's research on the functioning of students with mild intellectual disabilities in mainstream schools shows that $30 \%$ of them are rejected and $20 \%$ are isolated by their classmates without disabilities, which confirms the low social status of this group of students in mainstream schools. ${ }^{43}$ Adam Mikrut presents similar conclusions on the basis of his research, which shows intensified manifestations of various types of aggression and inter-peer violence against students with mild intellectual disabili-

${ }^{42}$ M. Chodkowska, „Problemy pedagogicznego wsparcia uczniów z niepełnosprawnością intelektualna w zakresie społecznego funkcjonowania w klasie szkolnej", [in:] Z. Palak, Z. Bartkowicz (eds.), Wsparcie społeczne w rehabilitacji i resocjalizacji, Wyd. UMCS, Lublin 2004.

43 A. Zamkowska, „Psychospołeczne i edukacyjne funkcjonowanie ucznia z upośledzeniem umysłowym w stopniu lekkim w szkole ogólnodostępnej”, [in:] Z. Gajdzica (ed.), Wspólne i swoiste zagadnienia edukacji i rehabilitacji osób z upośledzeniem umystowym, Wyd. Humanitas, Sosnowiec 2008, pp. 61-79. 
ties attending mainstream schools. ${ }^{44}$ This is also confirmed by data from the report on the implementation of Article 24 of the Convention on the Rights of Persons with Disabilities in Poland, prepared within the project „Wdrażanie Konwencji o Prawach Osób Niepełnosprawnych - wspólna sprawa" [Implementation of the Convention on the Rights of Persons with Disabilities - a common cause], according to which "All respondents confirmed a higher risk of discrimination against students with disabilities compared to their peers without disabilities. The most common justifications relate to social attitudes towards people with disabilities, stereotypical media coverage and dogmatism in education". ${ }^{5}$ According to Amadeusz Krause, "the essential advantages of a special education school - 'being among one's own' - should take precedence over other arguments as long as inclusive education means the dubious pleasure of "being among others" ${ }^{46}$

The least frequently indicated form of education was the mainstream school. Only $13 \%$ of respondent chose it as the best for a student with disabilities. They justified their choice of this form of education as follows:

In a mainstream school, a child can count on the help of their peers in addition to the help of teachers", "A child has the opportunity to grow up among healthy peers and will not feel like they're an outsider, like they're worse. The child will have the opportunity to pick up correct patterns of behaviour and social norms", "In a mainstream school the

44 A. Mikrut, „Uczniowie z upośledzeniem umysłowym jako ofiary międzyrówieśniczej przemocy i agresji w szkole ogólnodostępnej - wstępne rozeznanie problemu", [in:] Z. Gajdzica, A. Klinik, Watki zaniedbane, zaniechane, nieobecne w procesie edukacji $i$ wsparcia społecznego osób niepetnosprawnych, Wyd. Uniwersytetu Śląskiego, Katowice 2004.

45 "Report on the implementation of Article 24 of the Convention on the Rights of Persons with Disabilities in Poland, prepared as part of the 'Implementation of the Convention on the Rights of Persons with Disabilities - a common case' project" <https://www.dzp.pl/files/shares/Publikacje/Raport_tematyczny_art.24.pdf> [accessed ib 8.08. 2019].

46 A. Krause, Współczesne paradygmaty pedagogiki specjalnej, Oficyna Wydawnicza „Impuls”, Kraków 2011, p. 71. 
child has contact with other people and peers. The earlier they come into contact with the environment and understand it, the better off they will be in the future", "The presence of healthy children alongside children with disabilities positively affects their further development, especially in the social aspect", "After attending a mainstream school, a child will not have a difficult start in independent adult life", "[...] after attending a mainstream school, students with disabilities will find it easier in the future to adapt to life in society, and healthy students will find it easier to understand the essence of disability", $[. .$.$] the stu-$ dent will not feel like they stand out in society. They will be able to keep up with their peers to the best of their abilities".

Some respondents justified their choice of a mainstream school with their own experiences:

"There were students with disabilities at my school, so it was easier for us to adapt and it was normal to be around people with disabilities. Everyone treated each other as equal", "The mainstream school will prepare such a student for independent living, except in such a school you need to make other students aware of the person who will be with them in the class, what limitations they have, and how they can help that person", "Every person with a disability has the right to study in a mainstream school and they cannot be blocked or prohibited from it. I went to such a school myself. Learning together teaches tolerance, mutual help and acceptance. After attending such a school, people with disabilities are better adapted to life in society", "I think this is the best choice because the child does not feel 'different', they have friends among peers without disabilities. I myself attended such a school and had friends with disabilities".

The European Agency for Special Needs and Inclusive Education holds a similar position. A report the agency compiled presents the benefits of such inclusion for students with disabilities. "These benefits include: increased appreciation and acceptance of individual differences and diversity, respect for all people, preparation for adult life in an inclusive society and opportunities to master activities by practising and teaching others" ${ }^{47}$

47 European Agency for Special Needs and Inclusive Education, 2014. Five Key Messages for Inclusive Education. Putting Theory into Practice. Odense, Denmark: 
A small group of respondents argued their choice using support and understanding of the idea of inclusion and accepting diversity:

"Only a mainstream school enables full social development of a student with disabilities because it reflects the society in which the student lives every day", "Such a solution is beneficial for all because a mainstream school, according to the idea of inclusion, eliminates exclusion and social barriers, and additionally allows learning mutual acceptance. It is important that the institution prepares for the child, and not the other way around", "Thanks to attending a mainstream school, the child does not have a 'patch' of a special education school and has a greater chance of functioning as close as possible to healthy people", "A student with a disability is not excluded from the environment, they have contact with people without disabilities, which means they can count on understanding and support from healthy people. This also teaches healthy people that despite differences, we all have the same rights".

The analysis of the collected material has shown a consensus regarding the selection of the best system for students with disabilities. Respondents from all the studied fields of study indicated an integrated school as the best form of education, followed by a special education school. In the opinion of the surveyed groups, the least advantageous form of education for a student with disabilities is a mainstream school. As Katarzyna Ćwirynkało and Agnieszka Żyta point out, "despite the various positive aspects of this form of education being noted, it is not free from criticism. Similarly to other forms, it does not automatically lead to the elimination of educational obstacles". ${ }^{48}$ Dorota Kornas-Biela believes that the essence of these difficulties lies not only in the limited abilities of people with disabilities, but also in the attitudes of people without disabilities

European Agency for Special Needs and Inclusive Education, p. 14. <http:/ /www. european-agency.org/sites/default/files/Five \%20Key\%20Messages \%20for\%20Inclu sive \%20Education.pdf $>$ [accessed on 6.12.2019].

${ }^{48}$ K. Ćwirynkało, A. Żyta, „Przekonania nauczycieli na temat edukacji włączającej uczniów ze specjalnymi potrzebami edukacyjnymi. Raport z badań”, Szkoła Specjalna, 2015, no 4, p. 246. 
towards them. ${ }^{49}$ Despite the fact that the vast majority of respondents decided that shared education of students with and without disabilities is beneficial for both groups, ${ }^{50}$ the presented research results do not confirm these declarations and may serve as an example of subtle marginalisation and infrahumanisation, which allows the author to state that the thesis put forward in the introduction - that the condition for effective inclusive education is, first of all, maturity to diversity and internal consent to it, which is reflected in the attitudes accepting students with disabilities in a public school space.

\section{Conclusions}

The presented research results and their analysis do not justify generalisation of the problem, but they do signal the presence of subtle marginalisation and infrahumanisation, providing the basis for the statement that the above-mentioned phenomena are present both in actions in relation to people with disabilities and in thinking about them. When perceiving the welfare of people with disabilities, we do so from our own perspective. Often this perspective is not objective enough, because seen through the eyes of a person without disabilities, it misses the expectations of the people with disabilities themselves. We want to construct their world from the perspective of our own experiences, which generates conflicts and misunderstandings and promotes marginalisation. The analysis of students' statements concerning the justification for choosing the best form of education for students with disabilities reveals a picture of "us" - those without disabilities and "them" - people with

${ }^{49}$ D. Kornas-Biela, „Przekraczanie barier edukacyjnych w ujęciu pedagogiki niepełnosprawności Jeana Vaniera: inspiracje biograficzne", [in:] W. Żłobicki, B. Maj (eds.), Nierówności szans edukacyjnych. Przyczyny, skutki, koncepcje zmian, Oficyna Wydawnicza „Impuls”, Kraków 2012.

$5082 \%$ of the respondents answered definitely yes, $15 \%$ rather yes, 3\% rather no. None of the respondents indicated the answer definitely not. 
disabilities, whom we are still not able to fully accept in different areas of our lives. The presented opinions of students of pedagogical faculties show that by declaring a positive attitude towards shared education of students with and without disabilities, we find problems by means of which, under the guise concern for the welfare of people with disabilities, we subject them to infrahumanisation, attributing less favourable features to those who are "OtherAlien". Similar conclusions were drawn by J. Hughes, whose research on teachers' attitudes towards inclusive education showed that, despite the declared support for this idea, most teachers believe that mainstream schools are not the best place for children with disabilities. ${ }^{51}$ Beliefs and knowledge about disability will be conducive to certain behaviours. People tend to classify others according to categories, which favours intra-group assimilation and inter-group contrast. A person without a disability classifies a person with a disability as an "Other".52 Disability becomes a kind of label that creates categories and separates "us" from "them". The "Other" is the worse one, who needs to be helped, with whom we need to integrate, for whom we create special facilities so that they can function similarly to "us".

Teresa Żółkowska believes that despite changes in special education terminology (less marked), emerging concepts of integration, normalisation, independent living, changing living conditions, there are no changes at the level of relations, changes in the world of values. Despite progress, we have not achieved a satisfactory level of social participation of people with disabilities. ${ }^{53}$ Our mentality and perception of people with disabilities as weaker, worse is still the greatest barrier. We continue to subject this group to subtle marginalisation and infrahumanisation, attributing to it less advantageous features that prove the lack of independence and the possibility of

51 J. Hughes, "Inclusive education for individuals with Down syndrome”, Down syndrome News and Update, 2006, pp. 1-3.

52 M. Bełza, Ableizm a zjawisko..., op. cit., p. 81.

53 T. Żółkowska, Normalizacja niedokończona teoria..., op. cit., p. 88. 
making their own choices. And so, are we ready for diversity, for living together in the same social life space, with the same rights? Together, not next to each other. Together, not as "us" and "them" people with or without disabilities.

"We are all different, but we all live together on the same Earth, under one sky. It is worthwhile to conduct a dialogue between people of different faiths, nationalities,

races and views, between the poor and the rich, between people with and without disabilities,

old and young, people from the city and the countryside.

Such a conversation will change us and others, such a conversation will change the world.

Dialogue is about building reciprocity.

Rev. Prof. Józef Tischner

\section{Bibliography}

[1] Bąbka J., „Psychologiczne aspekty efektywności edukacji dzieci w systemie integracyjnym", [in:] Z. Kazanowski, D. Osik-Chudowolska (eds.), Integracja osób niepetnosprawnych w edukacji i integracjach społecznych, Wyd. UMCS Lublin 2003.

[2] Bank-Mikkelsen N.E., "A metropolitan area in Denmark: Copenhagen”, [in:] Changing patterns in residential Services. For the mentally retarded, R. Kugel, W. Wolfensberger (eds.), President's Committee on Mental Retardation, Washington 1969.

[3] Bank-Mikkelsen N.E., Warunki życia dla ludzi z upośledzeniem umystowym, Bruksela 1991.

[4] Baran T., „Pomiar zjawiska infrahumanizacji ‘obcych' poprzez atrybucję słów typowo ludzkich i typowo zwierzęcych", Psychologia Społeczna 2011, vol. 6.

[5] Bauman Z., Socjologia, Wydawnictwo Zysk i S-ka, Poznań 1996.

[6] Bełza M., "Ableizm a zjawisko infrahumanizacji 'obcych'”, Teraźniejszość-Człowiek-Edukacja, 2016, no. 2, pp. 77-87.

[7] Bełza M., „Inny/Obcy (uczeń niepełnosprawny) jako podmiot 'folkloru' szkolnego", [in:] Inkluzja edukacyjna. Idee, teorie, koncepcje, modele edukacji właczającej a wybrane aspekty praktyki edukacyjnej, Wydawnictwo Uniwersytetu Śląskiego, Katowice 2016.

[8] Chodkowska M., „Problemy pedagogicznego wsparcia uczniów z niepełnosprawnością intelektualna $\mathrm{w}$ zakresie społecznego funkcjonowania w klasie 
szkolnej", [in:] Z. Palak, Z. Bartkowicz (eds.), Wsparcie społeczne w rehabilitacji i resocjalizacji, Wyd. UMCS, Lublin 2004.

[9] Ćwirynkało K., Żyta A., „Przekonania nauczycieli na temat edukacji włączającej uczniów ze specjalnymi potrzebami edukacyjnymi. Raport z badań", Szkoła Specjalna, 2015, no 4, pp. 245-259.

[10] Demoulin S., Rodriguez R.T., Rodriguez A.P., Vaez J., Paladino M.P., Gaunt R., Cortes B.P., Leyens J.P., "Emotional prejudice can lead to infrahumanization", European Reviev of Social Psychology, 2004, no. 15, pp. 259-296.

[11] Duraj-Nowakowa K., Ksztattowanie profesjonalnej gotowości pedagogów, Wydawnictwo WAM, Kraków 2011.

[12] European Agency for Special Needs and Inclusive Education, 2014. Five Key Messages for Inclusive Education. Putting Theory into Practice. Odense, Denmark: European Agency for Special Needs and Inclusive Education, <http:// www.european-agency.org/sites/default/files/Five\%20Key\%20Messages \% 20 for \%20Inclusive\%20Education.pdf> [accessed on 6.12.2019].

[13] Fiske S.T., Cuddy A.J., Glick P., \& Xu J. (2002), “A model of (often mixed) stereotype content: Competence and warmth respectively follow from perceived status and competition", Journal of Personality and Social Psychology, 82(6), 2002, pp. 878-902.

[14] Frieske K.W., Encyklopedia Socjologii, Wydawnictwo Naukowe, Warsaw 1998.

[15] Gajdzica Z., „Opinie nauczycieli szkół ogólnodostępnych na temat edukacji włączającej uczniów z lekki upośledzeniem umysłowym w kontekście toczące się reformy kształcenia specjalnego", [in:] Z. Gajdzica (ed.), Uczeń z niepetnosprawnościa w szkole ogólnodostępnej, Oficyna Wydawnicza Humanitas, Sosnowiec 2011.

[16] Gajdzica Z., Uczniowie $i$ studenci z obszaru pogranicza wobec sytuacji osób niepetnosprawnych w środowisku lokalnym - nastawienia i opinie. Raport z badań, Wydawnictwo Arka, Cieszyn - Skoczów 2013.

[17] Głodkowska J., „Autorstwo życia a niepełnosprawność - ponawiane odczytywanie idei normalizacji", [in:] Człowiek - Niepetnosprawność - Społeczeństwo 2014, no. 1, pp. 75-96.

[18] Hughes J., "Inclusive education for individuals with Down syndrome”, Down syndrome News and Update 2006, no. 6, pp. 1-3.

[19] Kornas-Biela D., „Przekraczanie barier edukacyjnych w ujęciu pedagogiki niepełnosprawności Jeana Vaniera: inspiracje biograficzne", [in:] W. Żłobicki, B. Maj (eds.), Nierówności szans edukacyjnych. Przyczyny, skutki, koncepcje zmian, Oficyna Wydawnicza „Impuls”, Kraków 2012.

[20] Krause A., Integracyjne złudzenia ponowoczesności, Oficyna Wydawnicza „Impuls", Kraków 2000.

[21] Krause A., Wspótczesne paradygmaty pedagogiki specjalnej, Oficyna Wydawnicza „Impuls”, Kraków 2011. 
[22] Krause A., Żyta A., Nosarzewska A., Normalizacja środowiska społecznego osób $z$ niepetnosprawnościq intelektualną, Wydawnictwo Edukacyjne "AKAPIT", Toruń 2010.

[23] Leyens J., Demoulin S., Vaes J., Gaunt R., \& Paladino M.P., "Infra-humanization: The Wall of Group Differences", Social Issues and Policy Review, 1(1), 2007, pp. 139-172.

[24] Maciarz A., „Normalizacja szansą likwidacji społecznego upośledzenia osób niepełnosprawnych", [in:] Z. Janiszewska-Nieścioruk (ed.), Sfery życia osób z niepetnosprawnościa intelektualna, Oficyna Wydawnicza „Impuls”, Kraków 2005.

[25] Mudło-Głagolska K., Lewandowska M., „Edukacja inkluzyjna w Polsce”, Przeglad Pedagogiczny 2018, no. 2, pp. 202-214.

[26] Nirje B. (1969), "The normalization principle and its human management implications", [in:] R. Kugel, W. Wolfensberger (eds.), Changing Patterns in Residential Services for the Mentally Retarded. Washington, DC: President's Committee on Mental Retardation.

[27] Parys K., „Gotowość młodzieży gimnazjalnej do integracji pozaszkolnej z niepełnosprawnymi rówieśnikami", [in:] J. Szempruch (ed.), Edukacja wobec wyzwań i zadań wspótczesności i przyszłości, Wyd. Uniwersytetu Rzeszowskiego, Rzeszów 2006.

[28] „Realizacja zasady równości szans i niedyskryminacji, w tym dostępności dla osób z niepełnosprawnościami. Poradnik dla realizatorów projektów i instytucji systemu wdrażania funduszy europejskich 2014-2020", Ministerstwo Rozwoju, Warsaw 2015, <https://www.pois.gov.pl/media/23675/publikacja_ wersja_kontrastowa_3.pdf $>$ [accessed on 10.03.2019].

[29] "Report on the implementation of Article 24 of the Convention on the Rights of Persons with Disabilities in Poland, prepared as part of the 'Implementation of the Convention on the Rights of Persons with Disabilities - a common cause' project" <https://www.dzp.pl/files/shares/Publikacje/Raport_tematyczny_ art.24.pdf> [accessed on 8.08. 2019].

[30] Skotnicka B., "Gotowość do realizowania edukacji włączającej przez nauczycieli w szkołach ogólnodostępnych", Nauczyciel i szkoła 2015, no. 1, pp. 71-84.

[31] Skotnicka B., „Przygotowanie ogólnodostępnej szkoły wiejskiej do pracy z dzieckiem z orzeczoną potrzebą kształcenia specjalnego (na przykładzie szkół powiatu bydgoskiego)", unpublished part of doctoral dissertation.

[32] Tarnowska M., „Kiedy odmawiamy 'obcym' człowieczeństwa? Uwarunkowania zjawiska infrahumanizacji”, [in:] M. Kofta, M. Bilewicz (eds.), Wobec obcych. Zagrożenia psychologiczne a stosunki międzygrupowe, Wyd. Naukowe PWN, Warsaw 2011.

[33] Wilgocka-Okoń B., Gotowość szkolna dzieci sześcioletnich, Wydawnictwo Akademickie Żak, Warsaw 2003.

[34] Wiśniewski M., Haska A., „Społeczna mapa stereotypów”, Centrum Badań nad Uprzedzeniami, Warsaw 2012, <http://cbu.psychologia.pl/uploads/Raporty\%20 
\%20Deconspirator/Winiewski\&Haska_Deconspirator_mapa\%20stereotypow.pdf> [accessed on 4.08. 2019].

[35] Zamkowska A., „Psychospołeczne i edukacyjne funkcjonowanie ucznia z upośledzeniem umysłowym w stopniu lekkim w szkole ogólnodostępnej", [in:] Z. Gajdzica (ed.), Wspólne i swoiste zagadnienia edukacji i rehabilitacji osób z upośledzeniem umystowym, Wyd. Humanitas, Sosnowiec 2008.

[36] Żółkowska T., „Normalizacja niedokończona teoria praktyki”, Niepetnosprawność 2011, no. 5, pp. 85-93. <http:// bazhum.muzhp.pl/media// files/Niepelno sprawnosc/Niepelnosprawnosc-r2011-t-n5/Niepelnosprawnosc-r2011-t-n5-s85 -93/Niepelnosprawnosc-r2011-t-n5-s85-93.pdf> [accessed on 15.02. 2019]. 